\title{
ODNOS IZVRŠNIH FUNKCIJA I TEORIJE UMA U PREDŠKOLSKOJ DOBI
}

\author{
SANJA ŠIMLEŠA \\ Odsjek za logopediju, Edukacijsko - rehabilitacijski fakultet, Sveučilište u Zagrebu
}

Primljeno: 27.11.2019.

Prihvaćeno: 10.04 .2020 .
Izvorni znanstveni rad

UDK: $159.94-053.4$

159.922 .7

doi: $10.31299 /$ hrri.56.1.5

Sažetak: Povezanost i međudjelovanje izvršnih funkcija i teorije uma dosad nisu jasno definirani u psihološkim istraživanjima. Izvršne funkcije i teorija uma "igraju” značajnu ulogu u razvoju pojedinca i to počevši od jednostavnih obrazaca ponašanja dojenčeta pa do razvoja maštovite igre i autonomije djece, sve do planiranja i organizacije karijere i obitelji u ranoj odrasloj dobi. Cilj ovog rada bio je ispitati odnos odabranih aspekata izvršnih funkcija (inhibicijske kontrole, radnog pamćenja i kognitivne fleksibilnosti) i teorije uma za djecu u dobi četiri i pet godina te utvrditi koji od njih ima najveću prediktivnu vrijednost za postignuće na zadacima teorije uma. Kako bi se utvrdio međuodnos izvršnih funkcija i teorije uma u djece predškolske dobi, na uzorku od 203 djece dobi četiri i pet godina individualno je primijenjen niz zadataka za procjenu izvršnih funkcija (CANTAB baterija testova) $i$ teorije uma (NEPSY-II baterija testova). Rezultati su pokazali da je verbalno radno pamćenje značajan prediktor teorije uma za djecu u dobi od četiri godine, a verbalno radno pamćenje $i$ kognitivna fleksibilnost značajni su prediktori teorije uma u dobi od pet godina. Pritom je verbalno radno pamćenje najsnažniji pojedinačni prediktor teorije uma za obje dobne skupine. Zaključno razvoj u predškolskoj dobi vrlo je dinamičan; kognitivne se funkcije u funkciji kronološke dobi diferenciraju i restrukturiraju, a odnos izmedu varijabli izvršnih funkcija i teorije uma tijekom razvoja se mijenja.

Ključne riječi: izvršne funkcije, teorija uma, predškolska dob

\section{UVOD}

\section{Odnos izvršnih funkcija i teorije uma}

U samim počecima istraživanja teorija uma smatrala se urođenom zasebnom kognitivnom domenom koja se razvija neovisno o drugim kognitivnim domenama (Baron-Cohen, Leslie i Frith, 1985). Međutim u posljednje se vrijeme smatra da je razvoj teorije uma povezan s razvojem u nekim drugim kognitivnim domenama, posebno s razvojem izvršnih funkcija (Apperly, Samson i Humphreys, 2009; Kouklari, Tsermentseli i Monks, 2019). Različiti su razlozi zbog kojih se pretpostavlja da su izvršne funkcije i teorija uma razvojno povezane (Carlson i Moses, 2001). Kao prvo, u dobi između tri i pet godina djeca urednog razvoja pokazuju znatno poboljšanje kako na zadacima izvršnih funkcija (Diamond i Taylor, 1996) tako i na zadacima pogrešnih vjerovanja kojima se ispituje teorija uma (Wellman, Cross i Watson, 2001). Drugo, izvršne funkcije i teorija uma imaju zajedničku neu- ralnu osnovu; frontalni režanj (Siegal i Varley, 2002). Treće, smatra se da su u osnovi poremećaja iz spektra autizma poremećaji u pojedinim aspektima izvršnih funkcija i teorije uma, te da su ti poremećaji povezani (Zelazo, Jacques, Burack i Frye, 2002). U posljednjih nekoliko godina, istraživanje povezanosti između izvršnih funkcija i teorije uma postalo je jedno od najvažnijih pitanja $u$ istraživanjima razvojne psihologije. Postoje različita teorijska gledišta koja pokušavaju odgovoriti na pitanje interpretacije. Jedno je od njih pitanje prirode zadataka teorije uma. Prema ovom gledištu, iako djeca imaju razvijen koncept teorije uma, na zadacima teorije uma griješe zbog prevelikih izvršnih zahtjeva tih zadataka (Doherty, 2009). Ove su pretpostavke dovele do stvaranja teorije izražavanja teorije uma prema kojoj djeca imaju sposobnost teorije uma, ali pokazuju teškoće pri izražavanju iste zbog izvršnih zahtjeva koji su obilježja zadataka teorije uma (Moses, 2001).

Ipak, metaanaliza Wellmana i suradnika (2001) dovodi u pitanje postavke ove teorije. Naime ukoliko 
je razumijevanje netočnih vjerovanja "maskirano" izvršnim zahtjevima zadatka, smanjenje izvršnih zahtijeva trebalo bi dovesti do boljeg uratka u zadatku netočnih vjerovanja. Međutim Wellman i suradnici (2001) pronašli su skromno poboljšanje na zadacima netočnih vjerovanja uslijed smanjenja izvršnih zahtjeva zadatka te nisu pronašli poboljšanje kod mlađe djece. Upravo potaknuti tim nalazima većina istraživača danas odbacuje postavke ovog pristupa.

Prema drugom pristupu izvršne su funkcije pretpostavka razvoja teorije uma. Prema ovom gledištu određena sposobnost izvršnih funkcija nužna je za pojavu sposobnosti teorije uma. Ovakvo gledište naziva se teorija nastanka (Doherty, 2009). Prema njoj se smatra da su izvršne funkcije nužne za razvoj koncepta mentalnih stanja. Tako Russell (1996) tvrdi da su određeni procesi izvršnih funkcija, kao što su sposobnost nadgledanja vlastite aktivnosti te voljno djelovanje, nužni za odgovarajuću samosvijest koja je preduvjet razumijevanja mentalnih stanja.

Prema trećem je pristupu teorija uma pretpostavka razvoja izvršnih funkcija. Perner (1991) smatra da je metareprezentacija nužna za razvoj izvršnih funkcija. On ističe da je za razvoj sposobnosti planiranja nužno da osoba može predočiti svoje ili tuđe namjere, dok je za inhibicijsku kontrolu i mijenjanje seta nužno da osoba može reprezentirati znanje o tome da je uobičajen postupak neprikladan.

Četvrto gledište o vezi izvršnih funkcija i teorije uma kaže da se razvoj izvršnih funkcija i teorije uma može objasniti u terminima teorije kognitivne složenosti i kontrole (Zelazo i Frye, 1997). Prema toj teoriji kondicionalno je rezoniranje nužno za planiranje primjerene aktivnosti i inhibiranje neprimjerene aktivnosti. Napredak u kondicionalnom rezoniranju (primjerice ako - onda veze) omogućuje djeci da se usmjere na tekući problem i razviju primjeren plan i strategiju odgovora. Ista sposobnost smatra se nužnom za uspjeh u zadacima teorije uma, kao npr. na zadatku pogrešnih vjerovanja o mjestu gdje dijete treba analizirati plan djelovanja glavnog aktera pod različitim uvjetima.

\section{Istraživanja odnosa izvršnih funkcija i teorije uma}

Ovdje možemo postaviti pitanje koji su to procesi, odnosno koji su aspekti izvršnih funkcija povezani s teorijom uma? Istraživanja se uglavnom slažu da postoji povezanost inhibicije, radnog pamćenja i kognitivne fleksibilnosti s teorijom uma, međutim smjer navedene povezanosti još uvijek nije precizno utvrđen.

\section{Odnos inhibicijske kontrole i teorije uma}

Istraživanja su pokazala da su radno pamćenje, inhibicijska kontrola i kognitivna fleksibilnost značajno povezane s teorijom uma (Hughes, 1998). Carlson i Moses (2001) su pronašli visoku povezanost $(r=0,66, p<0,001)$ između teorije uma i baterije testova za ispitivanje inhibitorne kontrole (povezanost je bila značajna i nakon kontrole dobi, spola, receptivnog rječnika te dodatnih kontrolnih varijabli (broj braće i sestara te igra pretvaranja)). Oni su u svom radu dijelili zadatke za ispitivanje inhibitorne kontrole na zadatke sa zadrškom i konfliktne zadatke. Zadaci sa zadrškom zahtijevaju od djeteta samo da inhibira svoj odgovor, dok konfliktni zadaci (primjerice zadatak dan/noć) zahtijevaju od djeteta ne samo da inhibira neprikladan odgovor nego da aktivira novi, konfliktni odgovor. Taj dodatni proces koji zahtijeva držanje konfliktnih alternativa $u$ aktivnom pamćenju govori nam da su ti zadaci, osim inhibicijom, zasićeni i radnim pamćenjem. Carlson i Moses (2001) utvrdili su najsnažniju povezanost upravo između tih konfliktnih zadataka i teorije uma. Nadalje Carlson, Moses i Breton (2002) u svojoj su studiji potvrdili da neka kombinacija inhibicije i radnog pamćenja ima najvažniju ulogu u razumijevanju dječjeg shvaćanja pogrešnih vjerovanja, a Carlson Moses i Claxton (2004) ustanovili su korelaciju inhibitorne kontrole i teorije uma, ali ne i planiranja i teorije uma. Nadalje Carlson, Mandell i Williams (2004) otkrili su da su zadaci izvršnih funkcija (zadaci sa zadrškom i konfliktni zadaci) u djece u dobi od 24 mjeseca predviđali uradak na samo jednom, netipičnom zadatku teorije uma kod djece $u$ dobi od 39 mjeseci. $U$ navedenom zadatku (zadatak pretvaranja i stvarnosti; Zelazo, Reznick i Pinon, 1995) dijete $\mathrm{i}$ ispitivač se pretvaraju da konopac predstavlja zmiju. Zadatak je djeteta da odgovori što je predmet uistinu predstavljao kao i što on predstavlja sada. Nejasno je što se točno tim zadatkom mjeri. Rane izvršne funkcije nisu predviđale uradak na kasnijim zadacima netočnih vjerovanja i zadacima pojavnosti i stvarnosti. Također nijedan zadatak teorije uma u dobi od 24 mjeseca nije predviđao 
uradak u zadacima izvršnih funkcija u dobi od 39 mjeseci. Možemo zaključiti da iako su mjere inhibicije jasno povezane sa sposobnošću teorije uma, smjer navedene veze još je uvijek nejasan. Razlog za to može biti i sama složenost povezanosti između inhibicije i teorije uma koju možda nije ni moguće objasniti utjecajem jedne varijable na drugu.

\section{Odnos radnog pamćenja i teorije uma}

Istraživanja pokazuju da djeca pokazuju teškoće u zadacima teorije uma zato što ne mogu simultano obrađivati sve važne informacije potrebne za uspjeh u zadatku (Davis i Pratt, 1995). Utvrđena je umjerena povezanost između zadatka ponavljanja brojeva unatrag i zadataka netočnih vjerovanja $(r=0,48, p$ $<0,01)$. Također zadatak ponavljanja brojeva unatrag objasnio je malen, ali značajan dio varijance zadatka netočnih vjerovanja (Davis i Pratt, 1995).

Gordon i Olson (1998) utvrdili su primjenom zadataka za procjenu radnog pamćenja (Zadatak brojenja i imenovanja), u kojem se od djeteta zahtijeva simultano brojenje i imenovanje tri predmeta (primjerice "jedan je olovka, dva je ključ, tri je žaba"), značajnu pozitivnu povezanost tog zadatka s uspjehom u zadatku netočnih vjerovanja o sadržaju i zadatka pojavnosti i stvarnosti.

Navedena istraživanja jasno dokazuju povezanost radnog pamćenja i teorije uma. Postoje dva različita objašnjenja navedene povezanosti. Prvo bi bilo da svi zadaci radnog pamćenja istodobno zahtijevaju i određenu sposobnost inhibicije odgovora (Carlson i sur., 2002). Prema drugom je objašnjenju sposobnost radnog pamćenja preduvjet izvedbe zadataka teorije uma ili uopće preduvjet razvoja koncepta vjerovanja. Naime, neki autori (Gordon i Olson, 1998) smatraju da tek kada u umu mogu dvije reprezentacije držati aktivnima, djeca mogu razumjeti reprezentacijski koncept vjerovanja.

\section{Odnos kognitivne fleksibilnosti i teorije uma}

Kako bi se razumjela priroda povezanosti kognitivne fleksibilnosti i teorije uma, važno je osvrnuti se na konstrukt kognitivne fleksibilnosti. Neki autori kognitivnu fleksibilnost smatraju zasebnom sposobnošću (Colzato, Huizinga i Hommel, 2009) dok drugi smatraju da se radi o obilježju različitih kognitivnih procesa (Plunkett,
2006). Ponašanja koja se smatraju kognitivno fleksibilnima jesu: istovremeno sudjelovanje u više zadataka (eng. multitasking), promjena ponašanja uslijed novonastalih pravila, pronalaženje rješenja novonastalog problema i slično (Ionescu, 2012). Ako sagledamo sposobnost teorije uma, koja se definira kao razumijevanje mentalnih stanja drugih ljudi, možemo pretpostaviti da je ta sposobnost "zasićena" procesima kognitivne fleksibilnosti.

U pokušaju objašnjenja odnosa kognitivne fleksibilnosti i teorije uma, istraživači uglavnom koriste zadatak Razvrstavanje karata prema različitim dimenzijama (Zelazo i Frye, 1997) koji je u većini istraživanja pokazao povezanost sa zadacima teorije uma, čak i uz kontrolu dobi i verbalnih sposobnosti (Henning, Spinath i Aschersleben, 2011; Kloo i Perner, 2003; Muller, Zelazo i Imrisek, 2005). U tom zadatku ispitivač pokaže djetetu kartu s ucrtanim obojenim oblicima te mu kaže da prvo sortira karte po jednoj dimenziji (primjerice boji), a nakon toga po drugoj (primjerice obliku) te se promatra djetetova mogućnost promjene kognitivne udešenosti.

Četiri su različita pristupa kojima se objašnjava priroda povezanosti između dvaju navedenih konstrukta. Prema prvome pristupu složenost same strukture zadatka Razvrstavanje karata prema različitim dimenzijama dovodi do teškoća u izvedbi istog (Zelazo i Frye, 1997). Perner i Lang (2002) uklonili su ciljnu kartu, odnosno onu kartu na koju djeca slažu ostale karte prema zadanom kriteriju. Naime, u tom zadatku dvije ciljne lokacije razvrstavanja označene su kartama koje imaju istu, ali unakrsnu dimenziju kao i testna karta. Tako primjerice ukoliko su testne karte crveni zečevi i plavi automobili, ciljne su karte plavi zečevi i crveni automobili. Iako prema teoriji kognitivne složenosti i kontrole uklanjanje ciljnih karata ne bi trebalo poboljšati uradak u zadatku jer mu struktura ostaje ista, istraživanja pokazuju suprotno (Perner i Lang, 2002). Navedeno ne ide u prilog ovom pristupu.

Prema drugom pristupu djeca griješe u zadatku Razvrstavanje karata prema različitim dimenzijama zato što imaju teškoća u inhibiciji prethodnog točnog odgovora (Perner, Strummer i Lang, 1999). Jedan od nalaza koji ide u prilog ovom gledištu jest taj što djeca mogu izreći pravilo zadatka, ali ipak griješe u izvedbi kada se mijenja dimenzija razvrstavanja (Zelazo, Frye i Rapus, 1996). 
Istraživači trećeg pristupa smatraju da do teškoća u izvedbi dolazi zbog teškoća u inhibiciji pažnje, a ne odgovora, kao što se smatralo prema drugom pristupu. Kirkham, Cruess i Diamond (2003) smatrali su da je kod djece prisutna "tromost pažnje" (eng. attentional inertia). Oni objašnjavaju da djeca u prvoj fazi zadatka prosuđuju predmet na temelju njegove boje. Kada usvoje takvu mentalnu udešenost, pokazuju teškoće prebacivanja na drugu dimenziju (oblik). Da bi se djeca prebacila na drugu dimenziju, potrebna je inhibitorna kontrola pažnje. U svom istraživanju Kirkham i sur. (2003) od djece su zahtijevali da imenuju relevantnu dimenziju prije nego što polože testnu kartu na ciljnu kartu (u standardnom zadatku ispitivač imenuje relevantnu dimenziju). Takva promjena u izvedbi zadatka dovela je do usmjeravanja dječje pažnje na relevantnu dimenziju te poboljšala uradak u zadatku.

Prema četvrtom pristupu ovaj je zadatak djeci težak iz razloga što se od djeteta zahtijeva opisivanje podražaja na način drukčiji od prethodnoga. Odnosno, djeca u tom zadatku trebaju razumjeti da se jedna stvar može opisati na dva različita načina (Kloo i Perner, 2003). Također smatra se da je upravo sposobnost sagledavanja stvari na različite načine nužna i za uspjeh u zadacima netočnih vjerovanja. Kloo i Perner (2005) izmijenili su zadatak Razvrstavanje karata prema različitim dimenzijama na način da su koristili karte na kojima su dimenzije bile razdvojene. Primjerice umjesto plave banane na karti je ucrtana bezbojna banana pokraj plavog kruga. Ova je promjena u zadatku dovela do poboljšanja uratka, posebno kada su dimenzije bile razdvojene na testnim kartama. Smatra se da se upravo na taj način od djeteta zahtijeva sagledavanje podražaja na drugačiji način. Ovi rezultati, osim navedenog pristupa, potvrda su i pristupu koji naglašava "tromost pažnje" te se upravo ta dva pristupa smatraju osnovnim polazištem pri pokušaju objašnjenja povezanosti kognitivne fleksibilnosti i teorije uma.

U skladu s navedenim podacima te još uvijek neprecizno definiranom međuodnosu izvršnih funkcija i teorije uma, cilj ovog rada bio je ispitati odnos odabranih aspekata izvršnih funkcija (inhibicijske kontrole, radnog pamćenja i kognitivne fleksibilnosti) i teorije uma za djecu u dobi četiri i pet godina te utvrditi koji od njih ima najveću prediktivnu vrijednost za postignuće na zadacima teorije uma. Pretpostavlja se postojanje povezanosti svih aspekata izvršnih funkcija s teorijom uma u objema dobnim skupinama. Pritom bi zadaci radnog pamćenja trebali biti najsnažniji pojedinačni prediktori teorije uma u objema dobnim skupinama.

\section{METODOLOGIJA}

\section{Sudionici istraživanja}

U istraživanju je sudjelovalo ukupno 222 djece u dobi od 3,10 do 5,08 godina te njihovi roditelji koji su ispunili anamnestičke podatke te dali suglasnost za sudjelovanje u istraživanju. Podaci su prikupljeni u pet zagrebačkih vrtića. Iz daljnje analize izbačeni su rezultati petero djece za koju je naknadno utvrđeno postojanje zdravstvenih teškoća ili su uključena u neki oblik terapije te 14 djece koja su zbog različitih činitelja (motivacija, izostanak iz vrtića, umor uslijed trajanja testiranja) sudjelovala samo u jednom dijelu testiranja. U konačni je uzorak uključeno 203 djece urednog neverbalnog kognitivnog razvoja (izraženog rezultatom na podljestvici Razumijevanje kalupa WPPSI-III ljestvice inteligencije). U daljnjim analizama uzorak je podijeljen u dvije skupine, skupinu četverogodišnjaka i petogodišnjaka, izjednačenih po broju i spolu sudionika. Obilježja uzorka prikazana su u Tablici 1.

\section{MJERNI INSTRUMENTI}

\section{Intelektualne sposobnosti}

Podljestvica Razumijevanje kalupa (eng. Matrix Reasoning) korištena je za procjenu neverbalnih kognitivnih sposobnosti a dio je instrumenta WPPSI-III ljestvice inteligencije

Tablica 1. Prikaz obilježja uzorka $(N=203)$

\begin{tabular}{|c|c|c|c|c|c|c|c|c|c|c|c|c|c|}
\hline \multirow[b]{2}{*}{$N=203$} & \multicolumn{2}{|l|}{ spol } & \multicolumn{3}{|c|}{ redoslijed rođenja } & \multicolumn{4}{|c|}{ obrazovanje majke } & \multicolumn{4}{|c|}{ obrazovanje oca } \\
\hline & dječaci & djevojčice & 1. & 2. & $3-5$ & NSS & SSS & VSS & $\begin{array}{c}\text { magisterij/ } \\
\text { doktorat }\end{array}$ & NSS & SSS & VSS & $\begin{array}{c}\text { magisterij/ } \\
\text { doktorat }\end{array}$ \\
\hline frekvencija & 101 & 102 & 114 & 60 & 29 & 5 & 86 & 94 & 16 & 11 & 93 & 79 & 17 \\
\hline$\%$ & 49,8 & 50,2 & 56,2 & 29,6 & 14,2 & 2,5 & 42,4 & 47,3 & 7,9 & 5,4 & 45,8 & 38,9 & 8,4 \\
\hline
\end{tabular}


(eng. The Wechsler Preschool and Primary Scale of Intelligence - Third Edition; Wechsler 2002). Podljestvica Razumijevanje kalupa jedna je od tri osnovne podljestvice za procjenu neverbalne inteligencije djece dobi 4,00-7,03 godina. Ovu podljestvicu čine četiri različita tipa zadataka: kompletiranje, klasifikacija, zaključivanje po analogiji te serijalno zaključivanje. Sastoji se od tri zadatka za uvježbavanje te 29 zadataka, pri čemu svaki točan zadatak donosi jedan bod te je maksimalan broj bodova 29. Zadatak je ispitanika da između četiri ili pet predloženih sličica odabere onu sličicu koja nedostaje nepotpunoj matrici. Wechsler (2002) navodi kako je opravdano koristiti samu podljestvicu Razumijevanje kalupa kao mjeru neverbalne te opće kognitivne sposobnosti zbog visokih korelacija s neverbalnom $(r=.82)$ i općom $(r=.74)$ ljestvicom inteligencije. Podljestvica Razumijevanje kalupa u ovom je istraživanju korištena kao "ulazna" varijabla. Naime, kako bismo bili sigurni da uzorak sudionika čine samo djeca urednoga općeg kognitivnog statusa, kao probirnu mjeru koristili smo podljestvicu Razumijevanje kalupa. Koeficijenti pouzdanosti za podljestvicu Razumijevanje kalupa se u dobi između četiri i pet i pol godina kreću u rasponu od $\alpha=.89$ do $\alpha$ $=.91$ (Wechsler, 2002), dok pouzdanost izražena Cronbachovim alfa koeficijentom na našem uzorku iznosi $\alpha=.82$.

\section{Izvršne funkcije}

Izvršne funkcije procijenjene su Kembričkom automatiziranom neuropsihološkom baterijom testova (eng. Cambridge Neuropsychological Test Automated Battery-CANTAB) i odvojenim zadacima za ispitivanje izvršnih funkcija. CANTAB je neuropsihološka baterija testova koja se sastoji od niza kompjuterskih zadataka koji otkrivaju različite kognitivne deficite povezane s dobi is kliničkim poremećajima kod odraslih (vidi Fray, Robbins i Sahakian, 1996; Sahakian i Owen, 1992). Prvenstveno se koristi u istraživačke svrhe. CANTAB se sastoji od 22 testa koja se koriste za procjenu sljedećih kognitivnih domena: pažnja, brzina obrade, verbalno pamćenje, vizualno pamćenje te izvršne funkcije. Svi se testovi primjenjuju putem ekrana na dodir na računalu. Testovi su neovisni o jeziku i kulturi. Zadaci koje smo koristili u ovom istraživanju za ispitivanje izvršnih funkcija jesu: Prostorni raspon (eng. Spatial Span) i Unutardimenzijsko-izvandimenzijska promjena (eng. Intradimensional-Exstradimensional Shift).

\section{Inhibicijska kontrola}

NEPSY-II (Korkman, Kirk i Kemp, 2007) je mjerni instrument za procjenu neuropsihološkog razvoja predškolske i školske djece. Sastoji se od velikog broja podljestvica za procjenu u različitim domenama. Za procjenu izvršnih funkcija predškolske djece u NEPSY-II ljestvici u ovom istraživanju koristili smo podljestvicu Inhibicija.

Podljestvicom Inhibicija procjenjuje se sposobnost inhibiranja automatiziranog odgovora te stvaranje novog odgovora (dijete treba reći "krug" kada vidi oblik kvadrata, te "kvadrat" kada vidi oblik kruga). Za potrebe ovog istraživanja rezultat je izražen kao broj točnih odgovora. Broj podražajnih čestica iznosi 40. Pouzdanost izražena Cronbachovim alfa koeficijentom na našem uzorku iznosi 93.

Zadatak Trava-snijeg (Gerstadt, Hong i Diamond, 1994) - U ovom zadatku od djeteta se zahtijeva da pokaže bijelu kartu kada eksperimentator kaže "trava" te da pokaže zelenu kartu kada eksperimentator kaže "snijeg". Zadatak se sastoji od 16 pokušaja, uz napomenu da ispitivač ne podsjeća dijete na pravila zadatka. Rezultat sudionika za potrebe ovog istraživanja izražava se kao broj točnih odgovora. Pouzdanost izražena Cronbachovim alfa koeficijentom na našem uzorku iznosi .93.

\section{Radno pamćenje}

Prostorni raspon (eng. Spatial Span) CANTAB baterije testova je zadatak za ispitivanje vizualnog radnog pamćenja (Slika 1). Zadatak sudionika je da zapamti redoslijed kojim kvadrati na ekranu mijenjaju boje te da ih nakon signala dotakne onim redoslijedom kojim su izmijenili boje. U samom početku samo dva kvadrata od devet mogućih mijenjaju boju, a ukoliko sudionik uspješno rješava zadatak, povećava se i broj kvadrata koji mijenjaju boju. Sudionik ima ukupno tri pokušaja za pojedini niz. Vrijeme rada je neograničeno. Rezultat sudionika na ovom testu se izražava kao duljina raspona, 
odnosno najdulji niz koji je sudionik točno prizvao. Ukupan mogući rezultat na ovoj mjeri je 9.

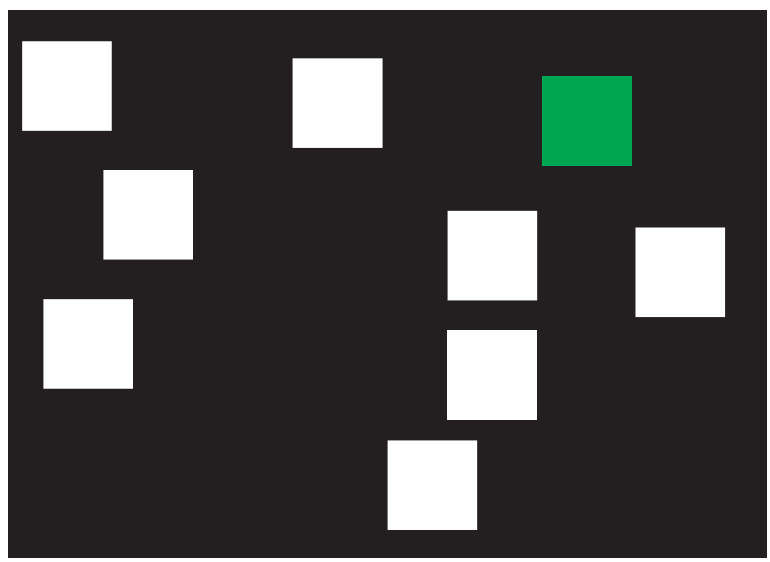

Slika 1. Prikaz zadatka Prostorni raspon (Cambridge Cognition CANTAB Tests)

Zadatak ponavljanja brojeva unatrag (Davis i Pratt, 1995) - Ispitivač predstavi djetetu lutku po imenu Luka i objasni mu da sve što on kaže Luka ponovi unatrag te mu pokaže primjer u kojem ispitivač kaže "jedan, dva" a Luka ponovi "dva, jedan". Nakon toga ispitivač predlaže djetetu da ponavlja brojeve unatrag, poput Luke. Ispitivač započne s dva broja te povećava broj znamenki sve dok dijete ne pogriješi na dva uzastopna pokušaja. Bilježi se najduži niz koji je dijete ponovilo.

\section{Kognitivna fleksibilnost}

Kognitivna fleksibilnost ispitana je zadatkom Unutardimenzijsko-izvandimenzijska promjena (Intra-Extra Dimensional Set Shift - IED) iz CANTAB baterije testova (Slika 2). Ovaj zadatak zahtijeva uočavanje pravila, kao i uočavanje obrasca mijenjanja tog pravila te brzu prilagodbu na novonastalu promjenu. Test je nastao na temelju Wisconsin testa razvrstavanja karata (eng. Wisconsin Card Sorting Test), s nekim prilagodbama za računalni oblik zadatka (Cambridge Cognition). Sastoji se od devet različitih stupnjeva, a zadatak je sudionika da između dva ponuđena ružičasta oblika nasumično odabere jedan za koji misli da je točan. Nakon što otkrije koji je traženi oblik točan, zadatak je sudionika da dotiče samo točne oblike. Na drugom se stupnju kriterij točnosti mijenja te sada drugi ružičasti oblik postaje traženi točni oblik. Na trećem stupnju zadatka dodaje se još jedan oblik (bijela linija različitih oblika) pored dva navedena ružičasta oblika, a na četvrtom su stupnju zadatka novi oblici polegnuti preko prva dva ružičasta oblika. Ta su dva nova bijela oblika na ovom stupnju irelevantna te sudionik i dalje treba doticati onaj ružičasti oblik za koji utvrdi da je točan (treći, četvrti i peti stupanj). Na šestom stupnju prva dva ružičasta oblika zamijenjena su novim oblicima, dok dva irelevantna bijela oblika koja su dodana na trećem stupnju i dalje ostaju. Sudionik i dalje treba doticati samo one oblike za koje utvrdi da su točni, a kriterij se točnosti između dva oblika mijenja (unutardimenzijska promjena). Na sedmom stupnju, osnovna se dva ružičasta oblika ponovno mijenjaju, a zadatak sudionika ostaje isti. Na osmom i devetom stupnju zahtijeva se izvandimenzijska promjena kognitivnog seta, odnosno nakon što je sudionik udesio kognitivni set za promjenu po jednoj dimenziji i unutar nje (ružičasti oblici), sada se od njega zahtijeva prebacivanje na drugu dimenziju koja do tada nije bila predmet odabira (bijela linija različitih oblika). Vrijeme je neograničeno, a rezultat se izražava kao broj pogrešaka te broj najvišeg stupnja koji je sudionik prešao. Za potrebe ovog istraživanja rezultat se izražava kao broj prijeđenih stadija unutar kojih dolazi do promjene kognitivne udešenosti.

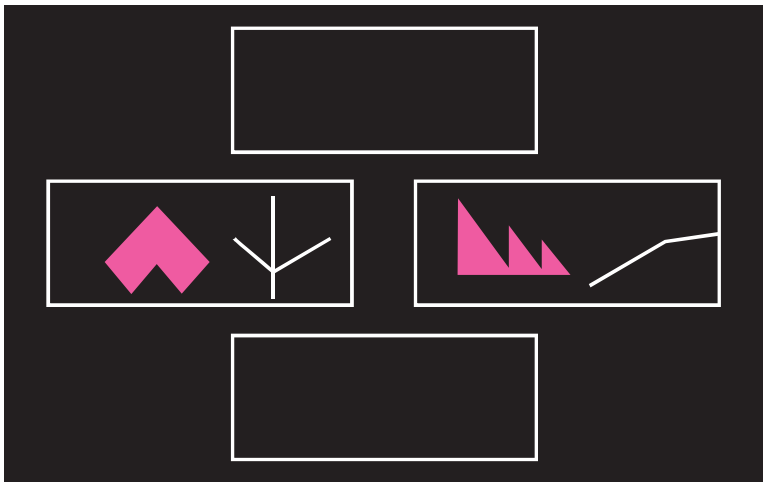

Slika 2. Prikaz zadatka Unutardimenzijskoizvandimenzijska promjena (Cambridge Cognition CANTAB Tests)

Zadatak Razvrstavanje karata prema različitim dimenzijama (Zelazo i sur., 1995) je zadatak u kojem se djetetu pokazuje karta s ucrtanim obojenim oblicima te se od njega traži da prvo razvrsta karte po 
jednoj dimenziji (npr. boji), a nakon toga po drugoj dimenziji (npr. obliku) te se promatra djetetova mogućnost promjene kognitivne udešenosti. Rezultat sudionika za potrebe ovog istraživanja izražava se kao broj točnih odgovora nakon promjene kognitivne udešenosti. Pouzdanost izražena Cronbachovim alfa koeficijentom na našem uzorku iznosi 0.65.

\section{Teorija uma}

Podljestvica Teorije uma NEPSY-II neuropsihološke baterije testova (Korkman i sur., 2007) zajedno s podljestvicom Prepoznavanje emocija čini domenu socijalne percepcije. Sastoji se od dvije vrste zadataka. U verbalnim zadacima (15 zadataka) djetetu se čitaju različite priče ili pokazuju slike, a da bi dijete točno odgovorilo na pitanje, $u$ zadatku treba razumjeti i uvažiti tuđu perspektivu. Te čestice procjenjuju sposobnost razumijevanja mentalnih funkcija kao što su želje, namjere, vjerovanja, prijevare, emocije, imaginacija, pretvaranje, kao i sposobnost razumijevanja da drugi ljudi imaju vlastite želje, namjere, znanja, vjerovanja, osjećaje koji mogu biti drugačiji od djetetovih. U zadacima su sadržani svi važni aspekti koji se odnose na konstrukt teorije uma. U kontekstualnim zadacima (šest zadataka) djetetu se pokažu slike na kojima je prikazana određena socijalna situacija u kojoj nije prikazano lice ciljne osobe. Dijete treba pokazati jednu od četiri ponuđene fotografije koja najbolje odgovara emociji koju bi ciljna osoba pokazala na slici, odnosno u toj određenoj socijalnoj situaciji.
Procjenjuje se djetetova sposobnost prepoznavanja emocija na osnovi fotografije lica kao i razumijevanje povezanosti emocija sa socijalnim kontekstom. Formiranje rezultata vrši se jednostavnom linearnom kombinacijom točnih rezultata za svaku od čestica, a viši rezultat označava bolju razvijenost teorije uma. Maksimalan broj bodova koji sudionik može postići jest 28 bodova. Vrijeme rada je neograničeno. Koeficijenti pouzdanosti za test teorije uma kreću se od 0.76 do 0.84 ovisno o dobi djeteta (Korkman i sur., 2007) dok pouzdanost izražena Cronbachovim alfa koeficijentom na našem uzorku iznosi $\alpha=0.52$. Razlog niže pouzdanosti na našem uzorku nego u ostalim istraživanjima vjerojatno možemo objasniti činjenicom da je test preveden na hrvatski jezik za potrebe ovog rada te uvidom u korelacijsku matricu između pojedinih čestica uviđamo da dva zadatka imaju nisku korelaciju s ostalim česticama što je dovelo do nešto nižeg Cronbachovog alfa koeficijenta na našem uzorku.

U nastavku u Tablici 2 je sažeti prikaz svih zadataka koji su se koristili u provedenom istraživanju.

\section{Postupak istraživanja}

Svi sudionici istraživanja ispitani su individualno. Istraživanje se provodilo u posebnim prostorijama pet zagrebačkih vrtića. Prilikom ispitivanja u prostorijama su bili prisutni samo ispitivač i dijete te se nastojalo osigurati standardne uvjete testiranja i u najvećoj mogućoj mjeri izbjeći smetnje koje bi mogle utjecati na djetetov uradak.

Tablica 2. Sažeti prikaz i osnovna obilježja mjernih instrumenata korištenih u provedenom istraživanju

\begin{tabular}{|l|l|c|c|c|l|l|}
\hline $\begin{array}{l}\text { naziv mjernog } \\
\text { instrumenta/zadatka }\end{array}$ & $\begin{array}{l}\text { domena koju } \\
\text { procjenjuje }\end{array}$ & $\begin{array}{c}\text { min. } \\
\text { mogući } \\
\text { rezultat }\end{array}$ & $\begin{array}{c}\text { maks. } \\
\text { mogući } \\
\text { rezultat }\end{array}$ & $\begin{array}{c}\text { dob za } \\
\text { koju je } \\
\text { namijenjen }\end{array}$ & $\begin{array}{l}\text { kako se izražava } \\
\text { rezultat? }\end{array}$ & $\begin{array}{l}\text { okvirno } \\
\text { trajanje } \\
\text { ispitivanja }\end{array}$ \\
\hline Inhibicija & $\begin{array}{l}\text { inhibicijska } \\
\text { kontrola }\end{array}$ & 0 & 40 & $4-16$ & broj točnih odgovora & $5-10$ minuta \\
\hline Trava/snijeg & $\begin{array}{l}\text { inhibicijska } \\
\text { kontrola }\end{array}$ & 0 & 16 & $3-5$ & broj točnih odgovora & $3-5$ minuta \\
\hline Ponavljanje brojeva unatrag & radno pamćenje & 0 & 5 & $4-6$ & $\begin{array}{l}\text { najduži ponovljeni } \\
\text { niz }\end{array}$ & $3-5$ minuta \\
\hline Prostorni raspon & radno pamćenje & 0 & 9 & $4-90$ & najduži ponovljeni & $10-15$ minuta \\
niz & $\begin{array}{l}\text { Razvrstavanje karata prema } \\
\text { različitim dimenzijama }\end{array}$ & $\begin{array}{l}\text { kognitivna } \\
\text { fleksibilnost }\end{array}$ & 0 & 6 & $3-5$ & broj točnih odgovora \\
nakon promjene seta & 5 minuta \\
\hline $\begin{array}{l}\text { Unutardimenzijsko- } \\
\text { izvandimenzijska promjena }\end{array}$ & $\begin{array}{l}\text { kognitivna } \\
\text { fleksibilnost }\end{array}$ & 1 & 9 & $4-90$ & broj prijedenih stadija & $15-25$ minuta \\
\hline Teorija uma & teorija uma & 0 & 28 & $3-16$ & broj točnih odgovora & $20-25$ minuta \\
\hline
\end{tabular}


Prije početka glavnog ispitivanja zatražena je suglasnost ravnatelja vrtića o provedbi istraživanja, a potom se uz pomoć stručnog tima vrtića napravio popis djece urednoga razvoja i odgovarajuće kronološke dobi kako bi se uključili u istraživanje. Ispitana su samo ona djeca za koju su roditelji potpisali suglasnost. Budući da je predviđeno vrijeme ispitivanja djeteta bilo oko dva sata, ispitivanje pojedinog djeteta je provedeno u dva navrata, ali s vrlo kratkim vremenskim razmakom (2-3 dana) kako bi prikupljanje podataka bilo vremenski usklađeno, čime se izbjegao utjecaj maturacije.

Prije provedbe zamišljenog protokola ispitivanja ispitivač je prvo ispitao dijete neverbalnom podljestvicom Razumijevanje kalupa WPPSI-III ljestvice inteligencije (Wechsler Preschool and Primary Scale of Intelligence - Third edition; Wechsler 2002) kako bi osigurao uzorak djece urednog intelektualnog funkcioniranja. Nakon toga slijedi glavno ispitivanje. Redoslijed zadavanja testova i zadataka na razini cijelog uzorka variran je po slučaju kako bi se kontrolirao učinak uvježbavanja i umora na uradak na testovima.

Nacrt istraživanja odobrilo je Etičko povjerenstvo Filozofskog fakulteta Sveučilišta u Zagrebu.

U istraživanju je uvažen djetetov individualni pristanak na suradnju te su u ispitivanju sudjelovala samo ona djeca koja su željela.

\section{Rezultati i rasprava}

S ciljem zahvaćanja različitih razvojnih aspekata sudionici su podijeljeni u dvije dobne skupine (četverogodišnjake i petogodišnjake) iz razloga što se pretpostavlja da se u funkciji dobi različite kognitivne domene sve više diferenciraju i da se obrazac odnosa između različitih kognitivnih domena u funkciji dobi mijenja te su analize rađene posebno za svaku dobnu skupinu. Stupanj razvijenosti pojedine sposobnosti u domeni izvršnih funkcija i teorije uma za pojedinu dobnu skupinu prikazan je u Tablici 3 .

Sve analize kojima je cilj bio odgovoriti na problem istraživanja provedene su uz statističku kontrolu varijabli za koje se pretpostavlja da bi, mimo prediktora, mogle utjecati na kriterijsku varijablu. Kontrola dobi sudionika učinjena je u skladu s teorijskim pretpostavkama o činiteljima povezanim s razvojem izvršnih funkcija (Fuster, 2002) i teorije uma (Doherty, 2009). Istraživanja pokazuju da u funkciji dobi dolazi do razvoja sposobnosti izvršnih funkcija i teorije uma. Nadalje, iako brojna istraživanja ne potvrđuju spolnu razliku na zadacima izvršnih funkcija i teorije uma, ipak neka istraživanja govore u prilog boljem postignuću djevojčica na zadacima teorije uma (Charman, Ruffman i Clements, 2002). Analizom spolnih razlika na našim podacima utvrđeno je da se djevojčice i dječaci statistički značajno razlikuju u nekim prosječnim vrijednostima na kriterijskim i prediktorskim varijablama. Iz tog razloga u provedenim statističkim analizama i spol je varijabla koja je kontrolirana. Konačno istraživanja pokazuju da obrazovanje majke pokazuje umjerene korelacije s izvršnim funkcijama (Sarsour i sur., 2011) i teorijom uma kod djece (Pears i Moses, 2003). Zbog navedenih teorijskih razloga kontrolirali smo i obrazovanje majke. Istraživanja nisu utvrdila jasnu ulogu obrazovanja oca za uspjeh u prediktorskim i/ili kriterijskim vari-

Tablica 3. Deskriptivne vrijednosti za varijable izvršne funkcije i teorija uma za dvije dobne skupine $(N=203)$

\begin{tabular}{|l|c|c|c|c|c|c|c|c|c|c|}
\hline \multirow{2}{*}{ naziv mjernog instrumenta/zadatka } & \multicolumn{4}{|c|}{ 4 godine } & \multicolumn{4}{c|}{ 5 godina } \\
\cline { 2 - 11 } & N & M & SD & Min & Max & N & M & SD & Min & Max \\
\hline Inhibicija (broj točnih odgovora) (IK) & 102 & 27.24 & 10.0 & 0 & 39 & 101 & 32.65 & 8.49 & 0 & 40 \\
\hline Trava/snijeg (broj točnih odgovora) (IK) & 102 & 11.22 & 5.30 & 0 & 16 & 101 & 13.86 & 3.02 & 0 & 16 \\
\hline Ponavljanje brojeva unatrag (najdulji niz) (RP) & 102 & 0.38 & 0.82 & 0 & 3 & 101 & 1.40 & 1.23 & 0 & 4 \\
\hline Prostorni raspon (najdulji ponovljeni niz) (RP) & 102 & 2.92 & 0.67 & 2 & 5 & 101 & 3.51 & 0.96 & 2 & 8 \\
\hline $\begin{array}{l}\text { Razvrstavanje karata(broj točnih odgovora } \\
\text { nakon promjene udešenosti) (KF) }\end{array}$ & 102 & 4.86 & 1.41 & 0 & 6 & 101 & 5.55 & 0.88 & 2 & 6 \\
\hline $\begin{array}{l}\text { Unutardimenzijsko-izvandimenzisjka promjena } \\
\text { (broj prijeđenih stadija) (KF) }\end{array}$ & 102 & 7.03 & 0.92 & 3 & 9 & 101 & 7.76 & 0.96 & 2 & 9 \\
\hline Teorija uma (broj točnih odgovora) & 102 & 11.76 & 2.49 & 5 & 18 & 101 & 13.78 & 2.57 & 4 & 21 \\
\hline
\end{tabular}

$\mathrm{N}$ - broj sudionika istraživanja; SD - standardna devijacija; Min - najmanji rezultat ; Max - najveći rezultat; IK - inhibicijska kontrola; RP - radno pamćenje; KF- kognitivna fleksibilnost 
jablama, a i s obzirom da je obrazovanje majke u visokoj korelaciji s obrazovanjem oca $(r=.5 ; p<$ $.01)$, u daljnjim analizama kao kontrolnu varijablu koristili smo samo varijablu obrazovanja majke.

Kako bismo odgovorili na cilj istraživanja, odnosno ispitali odnos različitih aspekata izvršnih funkcija i teorije uma, proveli smo hijerarhijske regresijske analize u kojima je kriterijska varijabla uradak u ljestvici teorije uma, a prediktorske su varijable uspješnost na zadacima izvršnih funkcija odnosno u zadacima inhibicijske kontrole, radnog pamćenja i kognitivne fleksibilnosti. Hijerarhijski model omogućuje nam izravnu usporedbu prediktivne "snage" pojedinih skupova varijabli. Hijerarhijske regresijske analize provedene su zasebno na skupini četverogodišnje $(\mathrm{N}=102)$ i petogodišnje djece $(\mathrm{N}=$ 101). Ispitanici su podijeljeni u dvije dobne skupine upravo iz razloga što se u dobi od četiri do pet godina događaju velike promjene u izvršnim funkcijama i teoriji uma te se pretpostavlja da će međuodnos izvršnih funkcija i teorije uma biti različit $u$ dvjema dobnim skupinama. Prediktorske varijable uvođene su u dva koraka. U prvom su koraku uvedene kontrolne varijable (dob, spol i obrazovanje majke), a u drugom koraku uveden je uradak na zadacima različitih izvršnih funkcija.

Rezultati hijerarhijske regresijske analize (Tablica 4) za sudionike u dobi od četiri godine pokazuju da regresijska jednadžba u prvom koraku nije statistički značajna, odnosno da na temelju kontrolnih varijabli nije moguće objasniti varijancu kriterija. Uvođenjem zadataka izvršnih funkcija u drugom koraku objašnjeno je dodatnih $9 \%$ varijance kriterija. Od svih zadataka za procjenu izvršnih funkcija samo je zadatak za procjenu verbalnog radnog pamćenja Ponavljanje brojeva unatrag značajan prediktor.

Rezultati hijerarhijske regresijske analize (Tablica 5) za sudionike u dobi od pet godina pokazuju da kontrolne varijable značajno objašnjavaju $12 \%$ varijance kriterija uz statistički značajne prediktore dob i obrazovanje majke. Uvođenjem zadataka izvršnih funkcija u drugom koraku objašnjeno je dodatnih $18 \%$ varijance kriterija. Od svih zadataka za procjenu izvršnih funkcija zadaci Ponavljanje brojeva unatrag i Unutardimenzijskoizvandimenzijska promjena pokazali su se kao značajni prediktori. ß koeficijenti varijabli dobi i obrazovanja majke smanjuju se i postaju statistič-
Tablica 4. Povezanost zadataka za procjenu izvršnih funkcija s teorijom uma za skupinu djece u dobi od četiri godine - rezultati hijerarhijske regresijske analize

\begin{tabular}{|l|c|c|}
\hline \multirow{2}{*}{ Prediktori } & \multicolumn{2}{|c|}{$\begin{array}{c}\text { Standardizirani } \\
\text { regresijski koeficijent - } \boldsymbol{\beta}\end{array}$} \\
\cline { 2 - 3 } & 1. korak & 2. korak \\
\hline Dob & .08 & .03 \\
\hline Spol $^{\mathrm{a}}$ & .14 & .06 \\
\hline Obrazovanje majke $^{\mathrm{b}}$ & .10 & .08 \\
\hline Zadatak Trava/snijeg & & .10 \\
\hline Zadatak Inhibicija & & .00 \\
\hline Ponavljanje brojeva & & $.21^{*}$ \\
\hline Prostorni raspon & & .04 \\
\hline Razvrstavanje karata & & .17 \\
\hline Unutardimenzijsko- & & .16 \\
izvandimenzijska promjena & & \\
\hline Sažetak modela: & & $.43^{*}$ \\
\hline $\mathrm{R}$ & .16 & $.09^{*}$ \\
\hline $\mathrm{R}^{2}$ kor & .00 & $.09^{*}$ \\
\hline$\Delta \mathrm{R}^{2}$ & .00 & \\
\hline
\end{tabular}

$* \mathrm{p}<.05 ; * \mathrm{p}<.01$.

a 1 = Muško, 2 = Žensko

${ }^{\mathrm{b}}$ od 1 (osnovna škola) do 4 (magisterij/doktorat).

ki neznačajni što upućuje na to da se utjecaj tih varijabli odvija preko varijabli verbalnog radnog pamćenja i kognitivne fleksibilnosti.

\section{Odnos inhibicijske kontrole i teorije uma}

Većina istraživanja potvrđuje umjerenu do visoku povezanost inhibicijske kontrole i teorije uma (Carlson i Moses, 2001; Carlson i sur., 2004; Cassetta, Pexman i Goghari, 2018). U provedenom istraživanju povezanost je između inhibicijske kontrole i teorije uma umjerena. Budući da je utvrđena povezanost oba zadatka kojima se procjenjuje inhibicijska kontrola i teorije uma, izračunato je pridonose li i u kolikoj mjeri ova dva zadatka objašnjenju rezultata u teoriji uma.

Rezultati hijerarhijske regresijske analize za sudionike u dobi od četiri i pet godina (Tablice 4 i 5) pokazuju da zadaci inhibicijske kontrole nisu značajni prediktori teorije uma. Razloge za takav nalaz možemo tražiti u samoj prirodi zadataka koje smo odabrali za procjenu inhibicijske kontrole. Naime, zadaci Trava/snijeg i Inhibicija u provedenom istraživanju pokazali su se prelaganima. U skladu s tim nema očekivanog varijabiliteta $u$ 
Tablica 5. Povezanost zadataka za procjenu izvršnih funkcija s teorijom uma za skupinu djece u dobi od pet godina - rezultati hijerarhijske regresijske analize

\begin{tabular}{|l|c|c|}
\hline \multirow{2}{*}{ Prediktori } & \multicolumn{2}{|c|}{$\begin{array}{c}\text { Standardizirani } \\
\text { regresijski koeficijent - } \boldsymbol{\beta}\end{array}$} \\
\cline { 2 - 3 } & $\mathbf{1 . ~ k o r a k}$ & $\mathbf{2 . ~ k o r a k}$ \\
\hline Dob & $.21^{*}$ & .16 \\
\hline Spol & .08 & .10 \\
\hline Obrazovanje majke & $.23^{*}$ & .11 \\
\hline Zadatak Trava/snijeg & & .08 \\
\hline Zadatak Inhibicija & & .02 \\
\hline Ponavljanje brojeva & & $.37^{* *}$ \\
\hline Prostorni raspon & & .13 \\
\hline Razvrstavanje karata & & .10 \\
\hline $\begin{array}{l}\text { Unutardimenzijsko- } \\
\text { izvandimenzijska promjena }\end{array}$ & & $.16^{*}$ \\
\hline Sažetak modela: & & \\
\hline $\mathrm{R}$ & $.36^{* *}$ & $.55^{* *}$ \\
\hline $\mathrm{R}^{2}$ kor & $.12^{* *}$ & $.30^{* *}$ \\
\hline$\Delta \mathrm{R}^{2}$ & $.12^{* *}$ & $.18^{* *}$ \\
\hline
\end{tabular}

$* \mathrm{p}<.05 ; * * \mathrm{p}<.01$.

a 1 = Muško, 2 = Žensko

b od 1 (osnovna škola) do 4 (magisterij/doktorat).

navedenim zadacima te je to vjerojatan razlog zbog kojeg se ti zadaci nisu pokazali kao snažni prediktori teorije uma. Također, kao što smo prije naveli, ovi su zadaci korišteni i u drugim istraživanjima za procjenu inhibicijske kontrole, međutim uglavnom za skupinu djece dobi od tri i četiri godine te su dobno primjereni za navedene skupine.

Također ako se osvrnemo na zadatke teorije uma kao i na ono što se podrazumijeva pod pojmom teorija uma u različitim dobnim skupinama, možemo vidjeti da su zadaci teorije uma ipak zasićeni inhibicijskom kontrolom. No djeca u dobi od četiri i pet godina imaju razvijene i druge sposobnosti i strategije koje im pomažu pri rješavanju zadataka teorije uma (primjerice jezične sposobnosti, pamćenja) te se nužno ne oslanjaju na sposobnost inhibicijske kontrole prilikom njihova rješavanja. Zadaci teorije uma u starijoj su dobi uglavnom jezični zadaci u kojima dijete treba zapamtiti priču te donijeti zaključak o mentalnom stanju druge osobe ili razumjeti preneseno značenje, ironiju i slično. U skladu s navedenim moguće je da različite mnemoničke strategije koje djeca primjenjuju da bi zapamtila priču također imaju velik utjecaj na rezultat u zadacima teorije uma $u$ toj dobi. Naime, djeca u dobi od pet do šest godi- na počinju aktivno koristiti mnemoničke strategije organizacije čestica u pojmovne kategorije (primjerice razvrstavanje hrane, životinja) (Moely, 1977) i elaboracije čestica povezivanjem s nekom slikom ili pričom (Kee i Guttentag, 1994).

Nadalje, mi smo u našem istraživanju koristili konfliktne zadatke za procjenu inhibicijske kontrole koji zahtijevaju od djeteta ne samo da inhibira neprikladan odgovor, nego da aktivira novi, konfliktni odgovor. Taj dodatni proces koji zahtijeva držanje konfliktnih alternativa u aktivnom pamćenju govori nam da su ti zadaci, osim inhibicijom, zasićeni i radnim pamćenjem. S obzirom na to da se u našem istraživanju verbalno radno pamćenje pokazalo najsnažnijim prediktorom, moguće je da se u navedenim zadacima više aktiviralo radno pamćenje.

Kako bi dobili jasniji uvid u prirodu veze inhibicijske kontrole i teorije uma, potrebno je provesti nova, eksperimentalna istraživanja u kojima bi se mijenjali izvršni zahtjevi zadataka teorije uma.

\section{Odnos radnog pamćenja i teorije uma}

Osim proučavanja odnosa inhibicijske kontrole i teorije uma istraživači su također u velikoj mjeri usmjereni na utvrđivanje odnosa radnog pamćenja i teorije uma. Većina istraživanja potvrđuje povezanost radnog pamćenja i teorije uma (Davis i Pratt, 1995; Gordon i Olson, 1998; Lecce i Bianco, 2018). Poznato je da su zadaci netočnih vjerovanja uglavnom konstruirani na način da se od djeteta traži rezoniranje o mentalnim stanjima druge osobe koja ima pogrešno vjerovanje o određenoj situaciji te dijete treba predvidjeti ponašanje ciljne osobe. Neka istraživanja kažu da u takvim zadacima djeca trebaju inhibirati pogrešan odgovor koji se temelji na činjeničnom znanju zadržanom u radnom pamćenju (Carlson i Moses, 2001; Leslie, Friedman i German, 2004). Druga istraživanja tvrde da pri rješavanju zadataka netočnih vjerovanja djeca trebaju izmijeniti kognitivnu udešenost između vlastitog mentalnog stanja i mentalnog stanja druge osobe, te je za "provedbu" tih aktivnosti ponovno odgovorno radno pamćenje (Andrews, Halford, Bunch, Bowden i Jones, 2003).

U provedenom istraživanju povezanost je između verbalnog radnog pamćenja i teorije uma umjerena, dok je povezanost između prostornog radnog pamćenja i teorije uma niska ali značajna. 
Za procjenu radnog pamćenja istraživači su uglavnom koristili zadatke za procjenu verbalnog radnog pamćenja. Nisu poznata istraživanja u kojima se kao mjera radnog pamćenja koriste i zadaci prostornog radnog pamćenja. S obzirom na to da su neki od zadataka teorije uma konstruirani u obliku slikovnog materijala u kojem primjerice uz vizualnu podršku dijete treba zapamtiti gdje se predmet nalazio u početku te gdje je predmet premješten, kao i osvijestiti da ciljna osoba nije vidjela da je predmet premješten (primjerice Sally i Ann), pretpostavili smo da i prostorno radno pamćenje može imati ulogu pri rješavanju zadataka teorije uma.

U provedenom istraživanju od dva zadatka za procjenu radnog pamćenja samo je zadatak verbalnog radnog pamćenja (Ponavljanje brojeva unatrag) značajan prediktor (Tablice 4 i 5). Analizom korelacijskih matrica možemo vidjeti da su dva zadatka za procjenu radnog pamćenja u niskim, odnosno u nultim korelacijama uz kontrolu varijabli dobi, spola i obrazovanja majke. To nas upućuje na zaključak da ta dva zadatka mjere različite aspekte radnog pamćenja. Također inspekcijom deskriptivne statistike uviđamo da je djeci u dobi od četiri godine zadatak Ponavljanja brojeva unatrag težak te većina djece taj zadatak ne uspijeva riješiti. Usprkos tome zadatak Ponavljanja brojeva unatrag pokazao se značajnim prediktorom teorije uma što znači da i vrlo mali napredak u sposobnosti verbalnog radnog pamćenja pridonosi uspješnosti djece na zadacima teorije uma.

Zadatak ponavljanja brojeva unatrag pokazao se najsnažnijim pojedinačnim prediktorom od svih zadataka za procjenu izvršnih funkcija, što može upućivati na to da verbalno radno pamćenje, u odnosu na druge procese izvršnih funkcija, ima najvažniju ulogu u razvoju teorije uma. Navedeno nas navodi na zaključak da djeca koja mogu simultano obrađivati više informacija imaju bolje razumijevanje reprezentacijskog koncepta želja, znanja i vjerovanja. Također, ako sagledamo zadatke za procjenu teorije uma, vidimo da su svi zadaci jako zasićeni radnim pamćenjem, odnosno dijete u navedenim zadacima treba simultano obrađivati više informacija istovremeno kako bi točno riješilo zadatak. Zbog toga je ovdje važno postaviti pitanje je li verbalno radno pamćenje značajan prediktor teorije uma iz razloga što su zadaci za procjenu teorije uma verbalni zadaci zasićeni radnim pamćenjem ili utječu na sam razvoj koncepta teorije uma (Gordon i Olson, 1998). Kako bi to provjerili, važno je "konstruirati" nove zadatke za procjenu teorije uma koji bi manje bili zasićeni jezičnim varijablama te provesti eksperimentalno istraživanje.

\section{Odnos kognitivne fleksibilnosti i teorije uma}

Osim proučavanja povezanosti inhibicijske kontrole i radnog pamćenja s teorijom uma, istraživači se bave i utvrđivanjem odnosa kognitivne fleksibilnosti i teorije uma. Većina istraživanja potvrđuje povezanost kognitivne fleksibilnosti i teorije uma (Bock, Gallaway i Hund, 2015; Henning i sur., 2011; Kloo i Perner, 2003; Muller i sur., 2005).

Rezultati dobiveni u ovom istraživanju (Tablice 4 i 5) pokazuju da zadaci kognitivne fleksibilnosti nisu značajni prediktori teorije uma u dobi od četiri godine, ali zadatak Unutardimenzijskoizvandimenzijska promjena značajan je prediktor teorije uma u dobi od pet godina.

Dobiveni rezultati mogu ukazivati na to da $\mathrm{u}$ dobi od četiri godine, kada djeca počinju razumijevati netočna vjerovanja na vrlo bazičnoj razini, sposobnost kognitivne fleksibilnosti, odnosno sposobnost opisivanja podražaja na jedan drugačiji način od prethodnog, možda nije toliko ključna za razumijevanje netočnih vjerovanja. No u dobi od pet godina, kada se od djeteta očekuje razumijevanje netočnih vjerovanja na nešto složenijoj razini, sposobnost razumijevanja da se jedna stvar može opisati na dva različita načina ključna je za uspjeh u zadacima netočnih vjerovanja (Kloo i Perner, 2003).

Zaključno, u ispitivanju odnosa izvršnih funkcija i teorije uma verbalno radno pamćenje pokazalo se značajnim prediktorom teorije uma u dobi od četiri godine, a verbalno radno pamćenje i kognitivna fleksibilnost značajnim prediktorima teorije uma $u$ dobi od pet godina. Pritom verbalno radno pamćenje predstavlja najsnažniji pojedinačni prediktor teorije uma za obje dobne skupine. Navedeno ide u prilog teorijama i istraživanjima koja smatraju da je sposobnost radnog pamćenja preduvjet izvedbe zadataka teorije uma ili uopće preduvjet razvoja koncepta vjerovanja. Već je spomenuto kako neki autori (Gordon i Olson, 1998) smatraju da tek kada u umu mogu dvije reprezentacije držati aktivnima, djeca mogu razumjeti reprezentacijski koncept vjerovanja. Iako u ovom istraživanju nismo imali eksperimental- 
ni nacrt, na temelju trenda dobivenih rezultata možemo se prikloniti teorijskom gledištu prema kojem su izvršne funkcije pretpostavka razvoja teorije uma. Prema ovom gledištu određena sposobnost izvršnih funkcija nužna je za pojavu sposobnosti teorije uma (Doherty, 2009), odnosno određeni procesi izvršnih funkcija kao što su sposobnost nadgledanja vlastite aktivnosti te voljno djelovanje nužni su za odgovarajuću samosvijest koja je preduvjet razumijevanja mentalnih stanja (Russell, 1996).

Doprinos ovog, u odnosu na dosadašnja istraživanja, očituje se prvenstveno u načinu mjerenja teorije uma. U ovom istraživanju sposobnost teorije uma mjerena je ljestvicom Teorije uma NEPSY-II standardizirane baterije testova te je rezultat na njoj izražen kao kontinuirana varijabla. U većini dosadašnjih istraživanja varijabla teorije uma mjerena je posebno konstruiranim zadacima na kojima se rezultat izražava kao dihotomna ili trihotomna varijabla (Carlson i Moses, 2001; Hughes i Ensor, 2007). Također doprinos je ovog istraživanja i utvrđivanje odnosa izvršnih funkcija i teorije uma za dvije različite dobne skupine, odnosno sudionike u dobi četiri i pet godina. Ta je dob sudionika odabrana upravo iz razloga što se tada događaju velike promjene u izvršnim funkcijama i teoriji uma, a većina dosadašnjih istraživanja kojima se pokušala utvrditi navedena povezanost rađena je za skupinu djece dobi tri i četiri godine (Carlson i Moses, 2001; Carlson i sur., 2004).

Prije izvođenja konačnih zaključaka dobivene rezultate potrebno je sagledati u kontekstu određenih nedostataka koji umanjuju mogućnost generalizacije dobivenih nalaza te upućuju na potrebu za daljnjim istraživanjem međuodnosa izvršnih funkcija i teorije uma. Ograničenje provedenog istraživanja predstavlja to što su podaci prikupljeni u jednoj točki mjerenja odnosno u okviru krossekcijskog nacrta istraživanja. Iako je većina istraživanja kojima se utvrđuje odnos izvršnih funkcija i teorije uma (Carlson i Moses, 2001; Carlson i sur., 2004)) provedena u jednoj točki mjerenja zbog ekonomičnosti istraživanja, ipak na temelju takvih istraživanja nije moguće govoriti o uzročno-posljedičnim odnosima. Najbolji pristup u istraživanju međuodnosa izvršnih funkcija, teorije uma i jezičnog razumijevanja bio bi longitudinalni.

Nadalje, još jedan metodološki nedostatak zasigurno predstavljaju i mjerni instrumenti korišteni u ovom istraživanju. Naime, za sav instrumentarij postoje samo prijevodi te oni nisu normirani i standardizirani za hrvatsko govorno područje. To je jedan od razloga zbog kojih su za nekoliko testova (primjerice podljestvicu Teorije uma) koeficijenti pouzdanosti bili niži od koeficijenata dobivenih $u$ ranijim istraživanjima, te je u skladu s tim nužan daljnji rad na njihovoj jezičnoj adaptaciji. Neki su od instrumenata relativno novi testovi (NEPSY-II) koji nisu mnogo korišteni u istraživanjima međuodnosa izvršnih funkcija i teorije uma zbog čega je otežana usporedba podataka s postojećom literaturom. Također neka od ograničenja tiču se mjernog instrumenta CANTAB. Naime, iako je CANTAB mjerni instrument koji se primjenjuje za cijeli životni raspon (od četiri do 90 godina), tijekom ispitivanja mogli smo zamijetiti da su četverogodišnjoj djeci neki zadaci bili teški i/ili dosadni te je ponekad teško reći je li uradak u zadatku rezultat sposobnosti djeteta ili motivacije i zamora. Također skupina četverogodišnje djece imala je većih teškoća u razumijevanju načina rada sa zaslonom osjetljivim na dodir (eng. touch screen).

Također važno je napomenuti da je uzorak sudionika nereprezentativan budući da je uočeno kako pristanak za sudjelovanje daju većinom roditelji koji smatraju da je njihovo dijete boljih kognitivnih sposobnosti. Također sramežljivija djeca obično nisu pristajala na sudjelovanje $u$ istraživanju, a moguće je da su zbog smanjenih socijalnih kontakata nešto nezrelija u sposobnosti teorije uma.

Osim znanstvenih postoje i određene praktične implikacije koje proizlaze iz ovog istraživanja. Razumijevanje međuodnosa izvršnih funkcija i teorije uma u djece urednoga razvoja nužna je pretpostavka za razumijevanje nekih razvojnih poremećaja. Razvojni poremećaji koji se često tumače teškoćom u barem jednoj od navedenih razvojnih domena su: poremećaj iz spektra autizma (Corbett, Constantine, Hendren, Rocke i Ozonoff, 2009; Girli i Tekin, 2010; Robinson, Goddard, Dritschel, Wisley i Howlin, 2009), poremećaj pažnje i hiperaktivnosti (Hill, 2004; Uekermann i sur., 2010) i posebne jezične teškoće (Bishop i Norbury, 2005; Farrant, Fletcher i Mayberry, 2006). Razumijevanje odnosa među istraživanim razvojnim domenama važno je u dijagnostici i terapiji razvojnih poremećaja. 


\section{LITERATURA:}

Andrews, G., Halford, G. S., Bunch, K. M., Bowden, D. i Jones, T. (2003). Theory of mind and relational complexity. Child Development, 74, 1476-1499.

Apperly, I. A., Samson, D. i Humphreys, G. W. (2009). Studies of adults can inform accounts of theory of mind development. Developmental Psychology, 45, 190-201.

Baron-Cohen, S., Leslie, A. M. i Frith, U. (1985). Does the autistic child have a theory of mind? Cognition, 21, 37-46.

Bishop, D. V. M. i Norbury, C. F. (2005). Executive functions in children with communication impairments, in relation to autistic symptomatology. 2: Response inhibition. Autism, 9, 29-43.

Bock, A. M., Gallaway, K. C. i Hund, A. M. (2015). Specifying links between executive functioning and theory of mind during middle childhood: Cognitive flexibility predicts social understanding. Journal of Cognition and Development, 16(3), 509-521.

Cambridge Cognition CANTAB Tests. Preuzeto s http://www.cantab.com/cantab-tests.asp.

Carlson, S. M., Mandell, D. J. i Williams, L. (2004). Executive function and theory of mind: Stability and prediction from ages 2 to 3. Developmental Psychology, 40, 1105-1122.

Carlson, S. M. i Moses, L. J. (2001). Individual differences in inhibitory control and children's theory of mind. Child Development, 72, 1032-1053.

Carlson, S. M., Moses, L. J. i Breton, C. (2002). How specific is the relation between executive function and theory of mind? Contributions of inhibitory control and working memory. Infant and Child Development, 11, 73-92.

Carlson, S. M., Moses, L. J. i Claxton, L. J. (2004). Individual differences in executive functioning and theory of mind: An investigation of inhibitory control and planning ability. Journal of Child Experimental Psychology, 87, 299-319.

Cassetta, B. D., Pexman, P. M. i Goghari, V. M. (2018). Cognitive and affective theory of mind and relations with executive functioning in middle childhood. Merrill-Palmer Quarterly, 64(4), 514-538.

Charman, T., Ruffman, T. i Clements, W. (2002). Is there a gender difference in false-belief development? Social Development, 11, 1-10.

Colzato, L. S., Huizinga, M. i Hommel, B. (2009). Recreational cocaine polydrug use impairs cognitive flexibility but not working memory. Psychopharmacology, 207, 225-234.

Corbett, B. A., Constantine, L. J., Hendren, R., Rocke, D. i Ozonoff, S. (2009). Examining executive functioning in children with autism spectrum disorder, attention deficit hyperactivity disorder and typical development. Psychiatry Research, 166, 210-222.

Davis, H. L. i Pratt, C. (1995). The development of children's theory of mind: The working memory explanation. Australian Journal of Psychology, 47, 25-31.

Diamond, A. i Taylor, C. (1996). Development of an aspect of executive control: Development of the abilities to remember what I said and to "Do as I say, not as I do". Developmental Psychobiology, 29, 315-334.

Doherty, J. M. (2009). Theory of Mind - How Children Understand Others' Thoughts and Feelings. Hove, UK: Psychology Press.

Farrant, B., Fletcher, J. i Mayberry, M. (2006). Specific language impairment, theory of mind, and visual perspective taking: Evidence for simulation theory and the developmental role of language. Child Development, 77, 1842-1853.

Fray, P. J., Robbins, T. W. i Sahakian, B. J. (1996). Neuropsychiatric applications of CANTAB. International Journal of Geriatric Psychiatry, 11, 329-336.

Fuster, J. M. (2002). Frontal lobe and cognitive development. Journal of Neurocytology, 31, 373-385.

Gerstadt, C. L., Hong, Y. J. i Diamond, A. (1994). The relationship between cognition and action: Performance of children 31/2- 7 years old on Stroop-like day-night test. Cognition, 53, 129-153. 
Hrvatska revija za rehabilitacijska istraživanja 2020, Vol 56, br. 1, str. $58-72$

Girli, A. i Tekin, D. (2010). Investigating false belief levels of typically developed children and children with autism. Procedia - Social and Behavioral Sciences, 2, 1944-1950.

Gordon, A. C. L. i Olson, D. R. (1998). The relation between acquisition of a theory of mind and the capacity to hold in mind. Journal of Experimental Child Psychology, 68, 70-83.

Henning, A., Spinath, F. M. i Aschersleben, G. (2011). The link between preschoolers' executive function and theory of mind and the role of epistemic states. Journal of Experimental Child Psychology, 108, 513-531.

Hill, E.L. (2004). Executive dysfunction in autism. Trends in Cognitive Sciences, 8, 26-32.

Hughes, C. (1998). Finding your marbles: Does preschoolers' strategic behavior predict later understanding of mind? Developmental Psychology, 34, 1326-1339.

Hughes, C. i Ensor, R. (2007). Executive Function and Theory of Mind: Predictive Relations From Ages 2 to 4. Developmental Psychology, 43, 1447-1459.

Ionescu, T. (2012). Exploring the nature of cognitive flexibility. New Ideas in Psychology, 30, 190-200.

Kee, D. W. i Guttentag, R. (1994). Resource requirements of knowledge access and recall benefits of associative strategies. Journal of Experimental Child Psychology, 57, 211-223.

Kirkham, N. J., Cruess, L. i Diamond, A. (2003). Helping children apply their knowledge to their behaviour on a dimension-switching task. Developmental Science, 6, 449-476.

Kloo, D. i Perner, J. (2003). Training transfer between card sorting and false belief understanding: Helping children apply conflicting descriptions. Child Development, 74, 1823-1839.

Kloo, D. i Perner, J. (2005). Disentangling dimensions in the dimensional change cardsorting task. Developmental Science, 8, 44-56.

Korkman, M., Kirk, U. i Kemp, S. (2007). NEPSY - Second Edition (NEPSY-II). San Antonio, TX: Harcourt Assessment.

Kouklari, E., Tsermentseli, S. i Monks, C. P. (2019). Developmental trends of hot and cool executive function in school-aged children with and without autism spectrum disorder: Links with theory of mind. Development and Psychopathology, 31(2), 541-556.

Lecce, S. i Bianco, F. (2018). Working memory predicts changes in children's theory of mind during middle childhood: A training study. Cognitive Development, 47, 71-81.

Leslie, A. M., Friedman, O. i German, T. P. (2004). Core mechanisms in "theory of mind". Trends in Cognitive Sciences, 8, 528-533.

Moely, B. E. (1977). Organizational factors in the development of memory. U: R. V. Kail i J. W. Hagen (Ur.), Perspectives on the development of memory and cognition. Hillsdale, NJ: Erlbaum.

Moses, L. J. (2001). Executive accounts of theory-of-mind development. Child Development, 72, 688-690.

Muller, U., Zelazo, P. D. i Imrisek, S. (2005). Executive function and children's understanding of false belief: How specific is the relation? Cognitive Development, 20, 173-189.

Pears, K. C. i Moses, L. J. (2003). Demographics, parenting, and theory of mind in preschool children. Social Development, 12, 1-20.

Perner, J. (1991). Understanding the representational mind. Cambridge, MA: MIT Press.

Perner, J., Stummer, S. i Lang, B. (1999). Executive functions and theory of mind: Cognitive complexity or functional dependence? U: P. D. Zelazo, J. W. Astington i D. R. Olson (Ur). Developing theories of intention: Social understanding and self-control (str. 133-152). Mahwah, NJ: Lawrence Erlbaum Associates, Inc.

Perner, J. i Lang, B. (2002). What causes 3-year-olds' difficulty on the dimensional change card sorting task? Infant and Child Development, 11, 93-105.

Plunkett, K. (2006). Learning how to be flexible with words. U: Y. Munakata i M. H. Johnson (Ur.), Attention and 
performance XXI: Processes of change in brain and cognitive development (str. 233-248). New York, NY: Oxford University Press.

Robinson, S., Goddard, L., Dritschel, B., Wisley, M. i Howlin, P. (2009). Executive functions in children with autism spectrum disorder. Brain and Cognition, 71, 362-368.

Russell, J. (1996). Agency: Its role in mental development. Hove, UK: Psychology Press.

Sahakian, B. J. i Owen, A. M. (1992). Computerised assessment in neuropsychiatry using CANTAB. Journal of the Royal Society of Medicine, 85, 399-402.

Sarsour, K., Sheridan, M., Jutte, D., Nuru-Jeter, A., Hinshaw, S. i Boyce, W. T. (2011). Family Socioeconomic Status and Child Executive Functions: The Roles of Language, Home Environment, and Single Parenthood. Journal of the International Neuropsychological Society 17, 120-132.

Siegal, M. i Varley, R. (2002). Neural system involved in "theory of mind". Nature Neuroscience, 3, 463-471.

Uekermann, J., Kraemer, M., Abdel-Hamid, M., Schimmelmann, B. G., Hebebrand, J. Daumb, I., Wiltfang, J. i Kis, B. (2010). Social cognition in attention-deficit hyperactivity disorder (ADHD). Neuroscience and Biobehavioral Reviews, 34, 734-743.

Wechsler, D. (2002). WPPSI-III Technical and Interpretive Manual. San Antonio, USA: The Psychological Corporation, Harcourt Assessment Company.

Wellman, H. M., Cross, D. i Watson, J. (2001). Meta-analysis of theory of mind development: The truth about false belief. Child Development, 72, 655-684.

Zelazo, P. D., Reznick, J. S. i Pinon, D. E. (1995). Response control and the execution of verbal rules. Developmental Psychology, 31, 508-517.

Zelazo, P. D., Frye, D. i Rapus, T. (1996). An age-related dissociation between knowing rules and using them. Cognitive Development, 11, 37-63.

Zelazo, P. D. i Frye, D. (1997). Cognitive complexity and control: A theory of the development of deliberate reasoning and intentional action. U: M. Stemenov (Ur.), Language structure, discourse, and the access to consciousness (str. 113-153). Amsterdam: John Benjamins.

Zelazo, P. D., Jacques, S., Burack, J. i Frye, D. (2002). The relation between theory of mind and rule use: Evidence from persons with autism-spectrum disorders. Infant and Child Development, Special Issue on Executive Functions and Development, 11, 171-195.

\section{THE RELATION BETWEEN EXECUTIVE FUNCTIONS AND THEORY OF MIND IN PRESCHOOL CHILDREN}

Abstract: The connection and interaction between executive functions and theory of mind have not yet been clearly defined in psychological research. Executive functions and theory of mind play a significant role in the development of the individual, starting from simple patterns of infant behaviour to the development of imaginative play and autonomy of children, through to planning and organising careers and families in early adulthood. The aim of the present study was to examine the relationship between selected aspects of executive functions (inhibitory control, working memory, and cognitive flexibility) and theory of mind for children aged four and five, and to determine which aspect has the greatest value for predicting achievement in tasks involving the theory of mind. In order to determine the relationship between executive functions and theory of mind in preschool children, a set of tasks was applied individually to a sample of 203 children aged four and five. Executive functions were evaluated using the CANTAB test battery, and theory of mind was assessed using the NEPSY-II test battery. Verbal working memory was a significant predictor of theory of mind in children as young as four, and verbal working memory and cognitive flexibility were significant predictors of theory of mind at the age of five. At both ages, verbal working memory was the strongest single predictor of theory of mind. These results suggest that pre-school development is very dynamic, cognitive functions differentiate and restructure with age, and the relationship between variables of executive functions and theory of mind changes during development.

Keywords: executive functions, theory of mind, preschool age 